\title{
4-(4-Chlorophenyl)pyrimidinium ylides. 1. Structure, stability, reactivity
}

\author{
Costel C. Moldoveanu, Geanina C. Mangalagiu, Gheorghita N. Zbancioc, Gabi Drochioiu, \\ Maria C. Caprosu, and Ionel I. Mangalagiu* \\ “Al. I. Cuza” University, Organic Chemistry Department, 11 Carol I Bd., \\ 700506 Iasi-6, Romania \\ E-mail: ionelm@uaic.ro
}

(received 03 Sept 04; accepted 04 Oct 04; published on the web 25 Oct 04)

\begin{abstract}
In this paper we present a theoretical and experimental study concerning the structure, stability, and reactivity of 4-(4-chlorophenyl)pyrimidinium ylides. 4-(4-Chlorophenyl)-pyrimidinium ylides are relatively stable compounds, their stability varying with the nature of the ylide carbanion substituent. The stronger the electron-withdrawing effect of these substituents, the more the anionic charge is delocalized, and therefore the higher their stability. The experimental and quantum chemical calculations confirm this hypothesis and are in accordance with each other. The electronic absorption spectra of 4-(4-chlorophenyl)-pyrimidinium 4-X-benzoyl methylides can be assigned to an intramolecular charge transfer band. The quantum chemical calculations show the possibility to use pyrimidinium ylides as nucleophilic reagents as well as 1,3-dipoles in reaction with appropriate reagents. The influence of microwave irradiation for the synthesis of azinium salts was also studied. The reaction of 4-(4-chlorophenyl)pyrimidine with an organic haloalkane shows a remarkable rate acceleration under microwave irradiation and allows a general and facile synthesis of azinium salts. A comparative study of microwave and classical conditions (use of solvents) has been done.
\end{abstract}

Keywords: Cycloimmonium ylides, pyrimidine, microwave, structure, stability, reactivity

\section{Introduction}

According to the literature indications ${ }^{1-20}$ the chemistry of cycloiminium ylides is widely discussed. In previous research work we have studied the synthesis, structure, and reactivity of some 1,2-diazinium ylides ${ }^{12-14}$ (derived from pyridazine and phthalazine) as well as of 1,3diazinium ylides ${ }^{15-17}$ (derived from 4-methylpyrimidine). Our main target was to study the chemistry of diazinium ylides and to find correlations between structure-stability-reactivityproperties [biological, ${ }^{18}$ acido-basic, ${ }^{19}$ electrical (semiconducting properties ${ }^{20}$ ) etc.]. The 
literature indications ${ }^{21-27}$ show that microwave irradiation is a new trend in organic chemistry offering a versatile and facile pathway in a large variety of syntheses. As far as the influence of microwave on the quaternisation reactions of heterocycles, few papers have been published in this respect. ${ }^{28-30}$

Continuing our research in the diazine series, we performed new investigations in the 1,3diazinium ylides series, having as the main goal to study thoroughly and broadly the chemistry of diazinium ylides. The influence of microwave irradiation concerning the synthesis of new pyrimidine compounds was another target. As starting material we chose 4-(4chlorophenyl)pyrimidine having in view that this heterocycle has not been studied in the literature.

In order to synthesize the basic heterocyle, 4-(4-chlorophenyl)pyrimidine, 3, we adapted the literature $^{31,32}$ method used for 4- and 4,5-substituted pyrimidines. The first step of the method consists of the synthesis of tris-( $N$-formylamino)methane, $\mathbf{1}$.

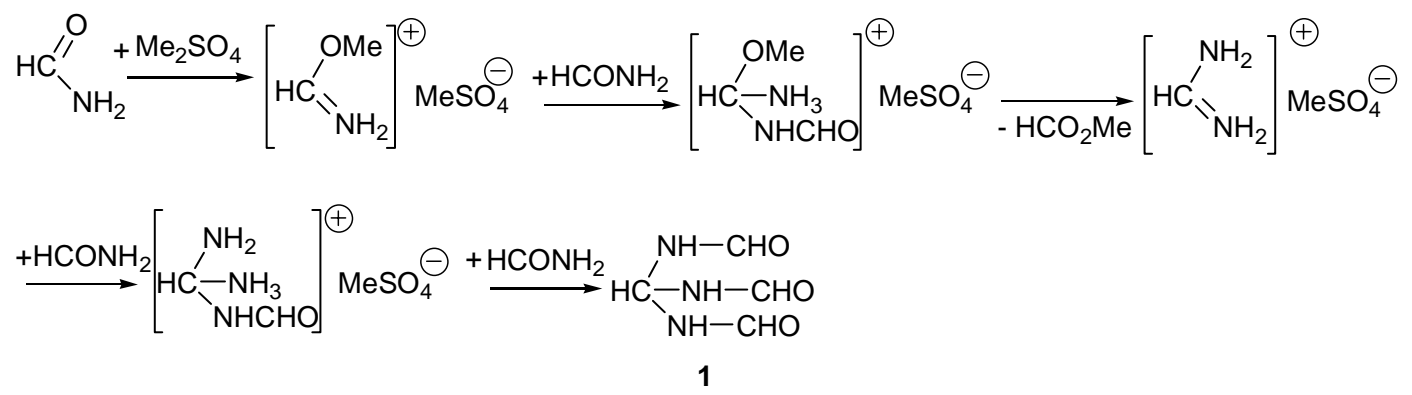

\section{Scheme 1}

In the second step, by condensation of 1 with 4-chloroacetophenone, 2, we obtained the basic heterocyle, 4-(4-chlorophenyl)pyrimidine, 3.

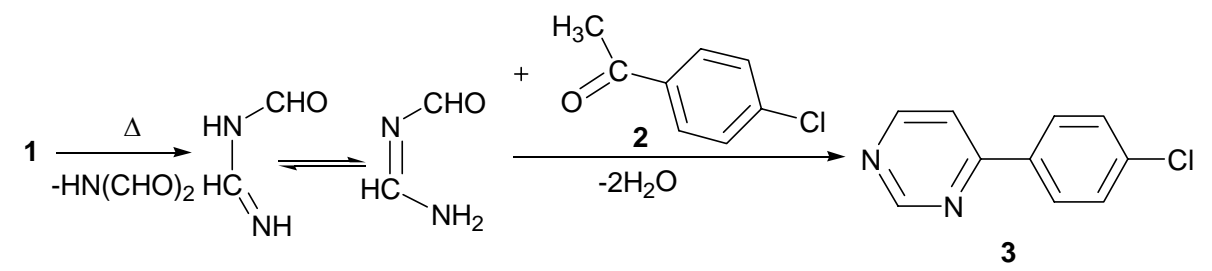

\section{Scheme 2}

In order to obtain new pyrimidinium ylides derived from 4-(4-chlorophenyl)-pyrimidine, we used the Kröhnke ${ }^{33}$ salt method. Thus, 1-[2-(4-X-phenyl)-2-oxoethyl]-4-(4chlorophenyl)pyrimidinium salts 4a-d were prepared by treating 4-(4-chlorophenyl)- pyrimidine 3 with 4-X-phenacyl bromides, which in aqueous solution of alkaline carbonates afforded the corresponding pyrimidinium ylides 5a-d. 


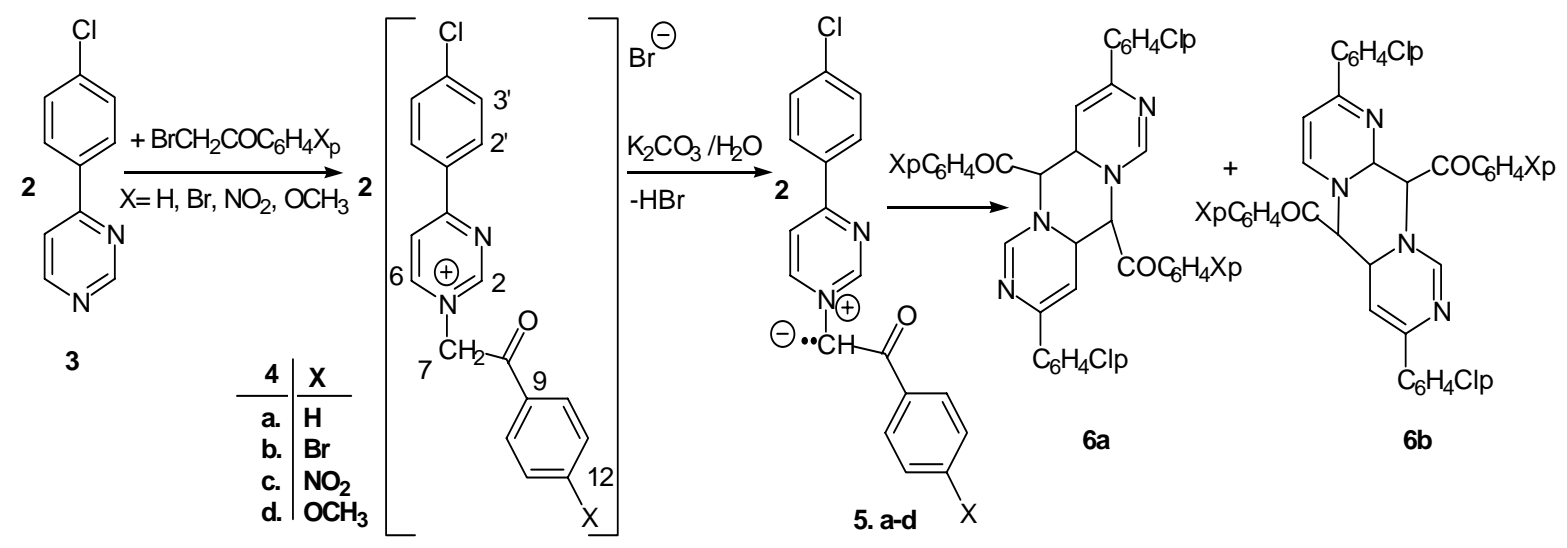

\section{Scheme 3}

A main disadvantage of the quaternisation of pyrimidine $\mathbf{3}$ is the fact that under classical heating conditions (refluxing in toluene) the reaction time is very long, viz. five days. Accordingly, we decided to synthesize the desired cycloiminium salts by microwave irradiation. In Table 1 are presented the reaction results obtained under microwave heating as well as under classical conditions (in order to allow a comparative study).

Table 1. Synthesis of cycloimmonium salts 4a-d under microwave heating and classical conditions

\begin{tabular}{lllllll}
\hline & \multicolumn{3}{l}{ Microwave } & \multicolumn{3}{l}{ Classical heating } \\
\cline { 2 - 7 } Salt & $\begin{array}{l}\text { Reaction } \\
\text { time }\end{array}$ & $\begin{array}{l}\text { Reaction } \\
\text { temperature, }{ }^{\circ} \mathrm{C}\end{array}$ & Yield, $\%$ & $\begin{array}{l}\text { Reaction } \\
\text { time }\end{array}$ & $\begin{array}{l}\text { Reaction } \\
\text { temperature, }{ }^{\circ} \mathrm{C}\end{array}$ & Yield, \% \\
\hline 4a & 20 min. & 90 & 61 & 5 days & 110 & 61 \\
4b & 20 min. & 90 & 62 & 5 days & 110 & 61 \\
4c & 20 min. & 90 & 73 & 5 days & 110 & 70 \\
4d & 20 min. & 90 & 53 & 5 days & 110 & 53 \\
\hline
\end{tabular}

As can be seen from Table 1, the yields are comparable for both methods, but under microwave irradiation the reaction times decrease dramatically from five days to twenty minutes.

In order to establish structure-stability-reactivity correlations in the 4-(4-chlorophenyl)pyrimidinium ylide series, we performed a theoretical study concerning these considerations. We used the General Theory of Perturbation Limited to the Frontier Molecular Orbitals. ${ }^{34-38}$ The geometry of the 4-(4-chlorophenyl)pyrimidinium benzoyl methylide 5a (for the energetically most favoured geometry, the heat of formation is $\Delta \mathrm{H}=63.174 \mathrm{kcal} / \mathrm{mol}$ ), the atomic charges, the coefficients of the atomic orbitals, and the values of the energies of the frontier molecular orbitals (Table 2) were calculated using the $\mathrm{PM} 3{ }^{38}$ method (for the other ylides the results are similar). 


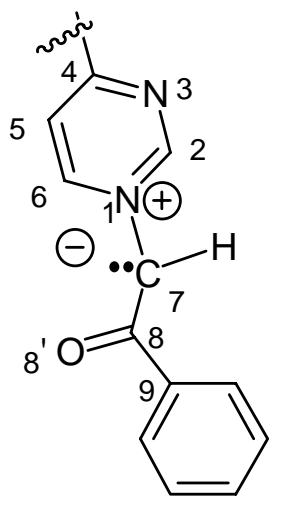

$\begin{array}{lr}\text { Bond distance (in pm) } \\ \text { N1-C2 } & 140.08 \\ \text { C2-N3 } & 134.00 \\ \text { N3-C4 } & 136.32 \\ \text { C4-C5 } & 140.62 \\ \text { C5-C6 } & 138.14 \\ \text { C6-N1 } & 139.05 \\ \text { N1-C7 } & 136.04 \\ \text { C7-C8 } & 145.07 \\ \text { C8-C9 } & 149.15 \\ \text { C8-O8' } & 123.24\end{array}$

$\begin{array}{lc}\text { Bond angle (in }{ }^{\circ} \text { ) } \\ \text { C6-N1-C7 } & 122.5416 \\ \text { C2-N1-C7 } & 120.3454 \\ \text { N1-C7-C8 } & 123.7691 \\ \text { C7-C8-C9 } & 115.5361 \\ \text { C7-C8-O8' } & 123.0933 \\ \text { Torsion angle (in }{ }^{\circ} \text { ) } \\ \text { C2-N1-C7-C8 } & -179.5401 \\ \text { C6-N1-C7-C8 } & 0.5228 \\ \text { N1-C7-C8-C9 } & 179.5476 \\ \text { N1-C7-C8-O8' } & 0.0753\end{array}$

Figure 1. Calculated Values.

As in related cases, ${ }^{17}$ the data from Figure 1 show the following:

- the ylide carbanion (C-7), the ylide nitrogen (N-1), and the $\alpha$-endocycle carbons (C-2 and C-6) are in the same plane (bond angles to the atoms involve around $120^{\circ}$ and the torsion angles $0^{\circ}$ or $\left.180^{\circ}\right)$;

- the bond distances: ylide carbanion (C-7) - ylide nitrogen $(\mathrm{N}-1), \mathrm{N}-1$ - C-2, N-1 - C-6 are around $140 \mathrm{pm}$ (intermediate between single and double bond).

An analysis of the data from Table 2 leads to the following conclusions:

- the ylide carbanion center, C-7, has a negative atomic charge, less than unity, but significant;

- the ylide nitrogen atom, N-1, has a positive atomic charge, less than unity, significant but smaller (in absolute value) than the ylide carbanion;

- the $\alpha$-endocyclic carbon atoms, C-2 and C-6, have small negative atomic charges, both being less than unity.

Table 2. The coefficients of atomic orbitals $\left(\mathrm{p}_{\mathrm{z}}\right)$, the total atomic charge (in $\mathrm{Q}$ ), and energies (in $\mathrm{eV}$ ) of ylide $5 \mathbf{a}$

\begin{tabular}{lllllllll}
\hline $\begin{array}{l}\text { Orbital } \\
\text { and } \\
\text { antomic }\end{array}$ & Energy & \multicolumn{6}{l}{ Coefficients of atomic orbitals $\left(\mathrm{p}_{\mathrm{z}}\right)$} \\
\cline { 2 - 8 } charge & & $\begin{array}{l}\mathrm{N}-1 \\
\text { (ylide) }\end{array}$ & $\begin{array}{l}\mathrm{C}-7 \\
\text { (ylide) }\end{array}$ & $\mathrm{C}-2$ & $\mathrm{C}-6$ & $\mathrm{~N}-3$ & $\mathrm{C}-8$ & $\mathrm{O}-9$ \\
\hline HOMO & -8.2448 & +0.0787 & -0.6013 & +0.3378 & +0.3089 & -0.1126 & -0.0908 & +0.2402 \\
LUMO & -1.3525 & +0.4739 & -0.2953 & -0.2113 & -0.1688 & -0.1807 & -0.2145 & +0.2118 \\
Q & & +0.8139 & -0.7991 & -0.4678 & -0.5336 & +0.0246 & +0.4602 & -0.3985 \\
\hline
\end{tabular}

The fact that the total atomic charges are less than unity indicates delocalization of the negative charge from the ylide carbanion center to the ylide substituents, and of the positive 
charge from the ylide nitrogen atom to the pyrimidine heterocycle, as shown in Figure 2; consequently a relatively good stability for these ylides follows. Introduction of electronwithdrawing substituents such as $\mathrm{X}=\mathrm{NO}_{2}$ (ylide 5c) leads to further delocalization of the negative charge; the opposite is valid for electron-releasing substituents such as $\mathrm{X}=\mathrm{OCH}_{3}$ (ylide 5d).

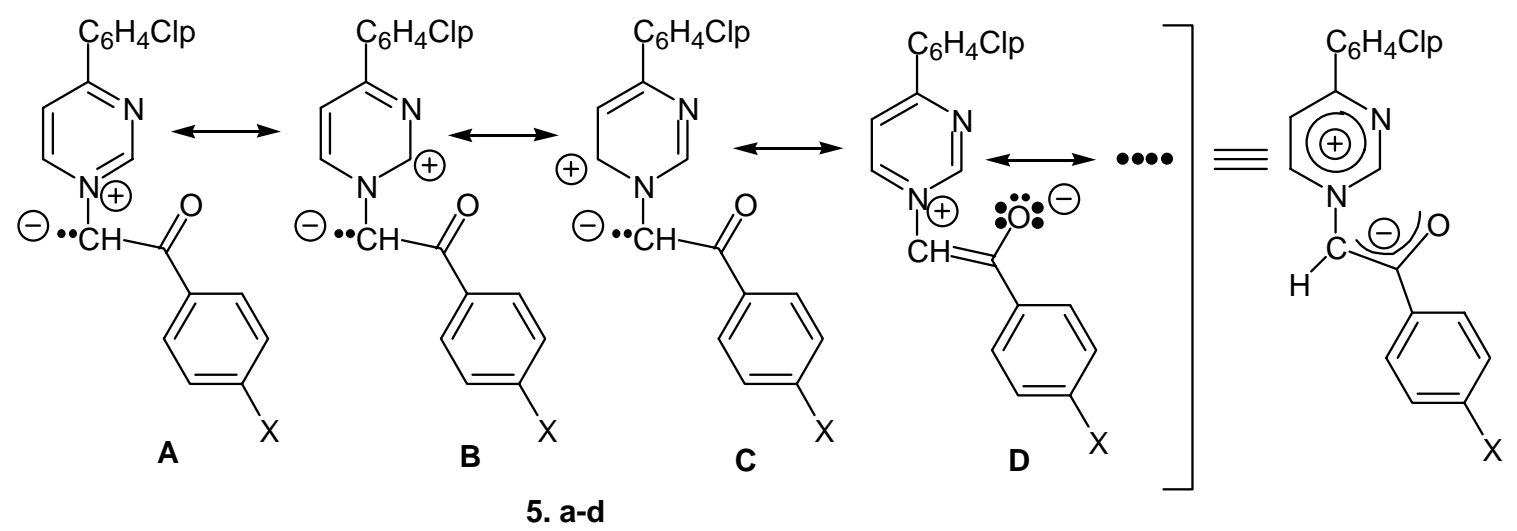

\section{Figure 2}

The fact that the ylide carbon atom has a significant negative atomic charge indicates that 1(4-chlorophenyl)pyrimidinium ylides could be used as nucleophilic reagents in appropriate reactions. Also, the data from Table 2 and Figures 1 and 2 show that ylides can have a 1,2dipolar mesomeric structure (octet form, canonical structure A), dipole which could accept a 1,3dipolar structure (sextet form without double bond, canonical structures B and C). The 1,3dipolar activity could involve either the 2- or the 6-position of the pyrimidine ring, a regiochemical problem. However, position 6 is less electron-deficient (atomic charge -0.5336) than position 2 (atomic charge -0.4678), therefore more suitable for reaction with an electronpoor dipolarophile. As in related cases, ${ }^{15,16}$ we expect that reactions of 4-(4chlorophenyl)pyrimidinium ylides with an electron-poor dipolarophile should occur as an ordinary [3+2] dipolar cycloaddition leading to azabicyclic compounds at the 2 or 6 positions.

The experimental data we obtained confirm the theoretical data presented above. Indeed, the new ylides, 5a-d, have different stabilities according to the nature of the 4-X-substituted benzoyl group. Thus, 4-(4-chlorophenyl)pyrimidinium 4-nitrobenzoyl methylide 5c is a stable compound. Pyrimidinium ylides 5a, 5b, and 5d are unstable, they undergo a rapid dimerisation process after preparation (via a [3+3] dipolar cycloaddition) leading to an ylide (5) - dimer (6) mixture, immediately after preparation of 5d, after 2-3 hours for 5a, and within 24 hours for $5 \mathbf{b}$. That means that, when the substituent $X$ has an electron-withdrawing effect (as the nitro group), delocalization of the negative ylide charge to the benzoyl group is favoured and consequently the stability of the ylide is higher. When the substituent $\mathrm{X}$ has a donor effect (as the methoxy group), delocalization of the negative ylide charge to the benzoyl group is not favoured, consequently 
the stability of the ylide decreases and the dimerisation process occurs easily. Having in view our previously expertise in related cases, ${ }^{16 b, 15,16 \mathrm{a}}$ we presume that a dimeric structure of type $6 \mathbf{6}$ (bispyrimidinopyrazine) is more likely than $\mathbf{6 b}$. Also, we found ${ }^{16 \mathrm{~b}}$ that the saturated bispyrimidinopyrazine is air sensitive and can undergo an oxidative process leading to a mixture of saturated and unsaturated bispyrimidinopyrazine compounds. No attempt was made to fully characterize these dimeric species.

Important information concerning the stability of ylides is furnished by the UV-VIS spectra. The literature data ${ }^{39}$ indicate that related diazinium ylides have in the visible range an intramolecular charge transfer (ICT) absorption band from the carbanion to the heterocycle. This absorption band is very sensitive to ylide carbanion substituents and, secondly, to the nature of the solvent.

The UV-VIS spectra of 4-(4-chlorophenyl)pyrimidinium 4-X-benzoyl methylides 5a-d were recorded in acetonitrile. The wavelengths at the maximum of the ICT band are the following $\left(\lambda_{\max }\right): 505 \mathrm{~nm}\left(\mathbf{5 c}, \mathrm{X}=\mathrm{NO}_{2}\right), 507 \mathrm{~nm}(\mathbf{b} \mathbf{b}, \mathrm{X}=\mathrm{Br}), 517 \mathrm{~nm}(\mathbf{5 a}, \mathrm{X}=\mathrm{H})$; ylide $5 \mathbf{d}\left(\mathrm{X}=\mathrm{OCH}_{3}\right)$ has no absorbance in the visible region. Analysis of these data reveals the following statements:

(a) 4-(4-Chlorophenyl)pyrimidinium 4-X-benzoyl methylides have a large absorption band around $\lambda=500 \mathrm{~nm}$. This band disappears when a small amount of hydrochloric (or sulphuric) acid is added which means that this band could be assigned to an intramolecular charge transfer (ICT) absorption band, Figure 3.

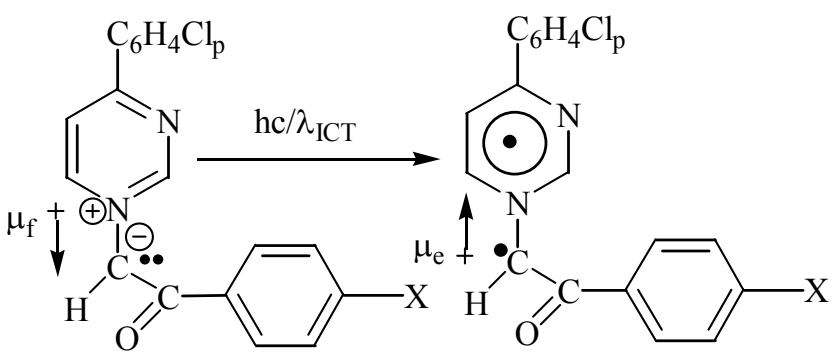

\section{Figure 3}

(b) The wavelengths of the ICT band maximum depend on the carbanion substituents. When $\mathrm{X}$ is a nitro group, the electron-withdrawing effect is stronger and there is an advanced delocalization of the anionic charge. Consequently, the ICT band appears at lower wavelengths. This is in accordance with the higher stability of the ylide $\mathbf{5 c}$.

The fact that ylide 5d does not absorb in the visible region can be explained by its low stability, (the dimerisation process occurs very rapidly and, when the spectrum is performed, we have mainly dimer which does not absorb in the visible region.)

The structures of the new pyrimidine compounds were proven through elemental and spectral (IR, UV-VIS, ${ }^{1} \mathrm{H}$ NMR, ${ }^{13} \mathrm{C}$ NMR, COSY, HMQC, HMBC) analyses.

Essential data are furnished by IR and NMR spectral analyses, Table 3. In the IR spectra of salts 4 the signals corresponding to ketone group are situated between $1629 \mathrm{~cm}^{-1}\left(\mathrm{X}=\mathrm{NO}_{2}, 5 \mathrm{c}\right)$ 
and $1625 \mathrm{~cm}^{-1}\left(\mathrm{R}=\mathrm{OCH}_{3}, 5 \mathbf{d}\right)$, in accordance with the effect of the substituent from the 4position of the aryl ring.

In the ${ }^{1} \mathrm{H}$ NMR spectra the most important signals are those of the $\mathrm{H}-2, \mathrm{H}-6$, and $\mathrm{H}-7$ atoms. As can be seen in Table 3, the H-2 atom appears around 9.80 ppm (singlet), H-6 around 9.45$9.40 \mathrm{ppm}$ (doublet, $J(6,5)=$ ca. $6.8 \mathrm{~Hz}$ ), and $\mathrm{H}-7$ appears around 6.70-6.40 ppm (singlet), in accordance with the proposed structure.

Table 3. Main spectral data of salts 4

\begin{tabular}{llllll}
\hline Salt & H-2 & H-6 & H-7 & ${ }^{13} \mathrm{C}-\mathrm{NMR}$ & $\mathrm{IR}, \mathrm{cm}^{-1}$ \\
\hline 4a & 9.85 & $9.48-9.46$ & 6.55 & $62.65(\mathrm{C}-7), 153.33(\mathrm{C}-6), 154.46(\mathrm{C}-2)$, & $1626\left(v_{\mathrm{CO}}\right)$ \\
& $\mathrm{s}$ & $\mathrm{d}, J(6,5)=6.8$ & $\mathrm{~s}$ & $190.24(\mathrm{C}-8)$ & \\
4b & 9.84 & $9.47-9.45$ & 6.54 & $62.13(\mathrm{C}-7), 153.00(\mathrm{C}-6), 154.11(\mathrm{C}-2)$, & $1628\left(v_{\mathrm{CO}}\right)$ \\
& $\mathrm{s}$ & $\mathrm{d}, J(6,5)=6.8$ & $\mathrm{~s}$ & $190.24(\mathrm{C}-8)$ & \\
4c & 9.93 & $9.56-9.54$ & 6.71 & $62.54(\mathrm{C}-7), 152.96(\mathrm{C}-6), 154.07(\mathrm{C}-2)$, & $1629\left(v_{\mathrm{CO}}\right)$ \\
& $\mathrm{s}$ & $\mathrm{d}, J(6,5)=6.8$ & $\mathrm{~s}$ & $190.24(\mathrm{C}-8)$ & \\
4d & 9.78 & $9.42-9.38$ & 6.42 & $62.10(\mathrm{C}-7), 153.01(\mathrm{C}-6), 154.11(\mathrm{C}-2)$, & $1625\left(v_{\mathrm{CO}}\right)$ \\
& $\mathrm{s}$ & $\mathrm{d}, J(6,5)=6.6$ & $\mathrm{~s}$ & $190.24(\mathrm{C}-8)$ & \\
\hline
\end{tabular}

${ }^{13} \mathrm{C}$ NMR spectra of salts 4 confirm also the structure: C-8: around $190 \mathrm{ppm}$ (alkyl-aryl ketone), C-2: 154 ppm, pyrimidine carbon ( $\alpha$-nitrogen, $\alpha$-positive nitrogen), C-6: 153 ppm, pyrimidine carbon ( $\alpha$-positive nitrogen, $\alpha$-carbon), C-7: 62 ppm, alkyl carbon ( $\alpha$-ketone, $\alpha-$ positive nitrogen from pyrimidine).

The IR spectrum of ylide 5c confirms the proposed structure. Thus, the signal for the ketone group appears at $1595 \mathrm{~cm}^{-1}$. The difference $v_{\mathrm{C}=\mathrm{O} \text { salt }} v_{\mathrm{C}=\mathrm{O} \text { ylide }}=34 \mathrm{~cm}^{-1}$ is in accordance with the delocalization phenomena of the negative charge from the ylide carbanion to the phenyl ring (Figure 2) and confirms our previous supposition.

The ${ }^{1} \mathrm{H}$ NMR of ylide $5 \mathrm{c}$ confirms also the structure. Thus, at $10.75 \mathrm{ppm}$ appears the signal of H-2 $\alpha$-endocyclic hydrogen atom (singlet). This signal appears at such low magnetic field due to the powerful deshielding effect exerted by the positive ylide nitrogen and the N-3 nitrogen. The signal of the ylide hydrogen, H-7, appears also at very low magnetic field due to the powerful deshielding effect exerted by the ylide positive nitrogen and ketone group.

All the remaining signals from IR and NMR spectra are in accordance with the proposed structure for the pyrimidine compounds.

The IR spectra and melting points of ylides $\mathbf{5 a}, \mathbf{5} \mathbf{b}$, and $\mathbf{5 d}$ show that we have a mixture of ylides and, probably, dimer 6. [one large ketone band centred around $1640 \mathrm{~cm}^{-1}$, large range of melting points]. 


\section{Conclusions}

1. The stability of 4-(4-chlorophenyl)pyrimidinium ylides varies with the nature of the ylide carbanion substituent. The higher the electron-withdrawing effect of these substituents, the more the negative charge is delocalized and therefore the higher their stability. The experimental and quantum chemical calculation data confirm this hypothesis and are in accordance with each other.

2. The quantum chemical calculations show the possibility of using pyrimidinium ylides as nucleophilic reagents as well as 1,3-dipoles in reaction with appropriate reagents.

3. The microwave enhanced reaction of 4-(4-chlorophenyl)pyrimidine and an organic haloalkane shows a remarkable rate of acceleration under microwave irradiation. A rapid, facile and general synthesis of cycloimmonium salts using nitrogen heterocycles and haloalkanes under microwave heating was demonstrated.

4. The electronic absorption spectra of 4-(4-chlorophenyl)pyrimidinium 4-X-benzoyl methylides can be assigned to an intramolecular charge transfer (ICT) absorption band.

5. The position of the ICT band depends essentially on the carbanion substituents. The higher the delocalization of the negative charge along the carbanion is, the higher the wavenumber of the ICT band will be. The UV-VIS data show that ylide $\mathbf{5 c}$ has a higher stability, which is in accordance with our previous consideration concerning the stability of pyrimidinium ylides.

6 . Eight new pyrimidine compounds (4 salts, and 4 ylides) were obtained.

\section{Experimental Section}

General Procedures. Melting points were determined on a MELTEMP II apparatus and are uncorrected. ${ }^{1} \mathrm{H}$ and ${ }^{13} \mathrm{C}$ NMR spectra were recorded on a Bruker Avance instrument $(400 \mathrm{MHz})$ with $\mathrm{SiMe}_{4}$ as internal standard. IR spectra were recorded with a JASCO V-570 spectrometer. UV-VIS spectra were recorded with a Hitachi U-2010 spectrometer. For the microwave irradiation we used a monomode reactor STAR-2, CHEM Corporation $(50 \mathrm{~W})$. The quantum chemical calculations have been done using a HYPERCHEM 5. 02 program.

4-(4-Chlorophenyl)pyrimidine (3). Into a three-necked flask (condenser, thermometer, and vacuum) were placed $4 \mathrm{~mol}(150 \mathrm{~mL})$ formamide and $0.4 \mathrm{~mol}(38 \mathrm{~mL})$ dimethyl sulphate. The reaction mixture was heated $\left(80-90{ }^{\circ} \mathrm{C}\right)$ at low pressure for $2 \mathrm{~h}$ and the resulted methyl formiate was vacuum distilled off. Than vacuum was removed and $0.1 \mathrm{~mol}(13 \mathrm{~mL})$ 4-chloroacetophenone and $1 \mathrm{~g}$ of 4-toluenesulphonic acid was added. The resulting mixture was than heated for $8 \mathrm{~h}$ at $150-160^{\circ} \mathrm{C}$. After cooling at room temperature, $250-300 \mathrm{~mL}$ aqueous $\mathrm{NaOH}$ $1 \mathrm{~N}$ was added slowly and extracted with chloroform $(10 \times 15 \mathrm{~mL})$. The combined organic fractions were dried over $\mathrm{MgSO}_{4}$, the solution was filtered and chloroform is distilled off in vacuo. The crude product was purified by recrystallization from benzene - petroleum ether. 
After filtration, the crystals were dried under vacuo at $45-50^{\circ} \mathrm{C}$ and gave $3(11.82 \mathrm{~g}, 62 \%)$. 3: $\mathrm{mp}$ $82{ }^{\circ} \mathrm{C}$ (yellow crystals, recrystallized from benzene - petroleum ether). IR (KBr): 1678, 1577 , 1458, 1387, 1090 (s, C=C, C=N arom), 820, 772 (s, C-H $\mathrm{H}_{\text {arom }}$ def), 486, 465 (m, C-Cl), 3034 (w, C-H arom$_{\text {) }} \mathrm{cm}^{-1}$. ${ }^{1} \mathrm{H}$ NMR $\left(\mathrm{CDCl}_{3}\right) \delta: 9.29(1 \mathrm{H}, \mathrm{s}), 8.78-8.77(1 \mathrm{H}, \mathrm{d}, J=5.6 \mathrm{~Hz}), 8.05-8.03(2 \mathrm{H}, \mathrm{d}, J=8.0 \mathrm{~Hz}), 7.69-7.68$ $(1 \mathrm{H}, \mathrm{d}, J=5.6 \mathrm{~Hz}), 7.50-7.47(2 \mathrm{H}, \mathrm{d}, J=8.0 \mathrm{~Hz}) .{ }^{13} \mathrm{C}$ NMR: $116.74(\mathrm{C}-5), 128.41$ (C-2'), 129.30 (C3'), 134.87 (C-4'), 137.42 (C-1'), 157.64 (C-6), 159.13 (C-2), 162.66 (C-4). Anal. Calcd. for $\mathrm{C}_{10} \mathrm{H}_{7} \mathrm{~N}_{2} \mathrm{Cl}$ : C, 63.00; H, 3.70; N, 14.69. Found: C, 62.95; H, 3.69; N, 14.58\%.

\section{General procedure A to obtain pyrimidinium salts under classical heating}

4-(4-Chlorophenyl)pyrimidine $(0.95 \mathrm{~g}, 5 \mathrm{mmol})$ and $\omega$-bromo-4-X-acetophenone (5 mmol) was dissolved in $20 \mathrm{~mL}$ toluene. The solution was heated to reflux, stirring, for 5 days. The pyrimidinium salts obtained were filtered off and dried in vacuo, then purified by recrystallization from diethyl ether.

\section{General procedure B to obtain pyrimidinium salts under microwave}

Caution! It is hazardous to heat rapidly the reactions with microwave irradiation. Therefore, caution should be exercised when carrying out reactions of this type. A typical procedure for the synthesis of cycloimmonium salts is as follows: Nitrogen heterocycle $(5 \mathrm{mmol})$ and haloalkane ( $5 \mathrm{mmol}$ ) are added in a tube (Pyrex glass or quartz) in which $20 \mathrm{~mL}$ of toluene were previously placed. The tube is then placed in the microwave cell (could be used one or both cells of the STAR reactor) and heated for the appropriate time. Stirring of the reaction mixture is desirable. When a stirring device is not accessible, it can be replaced with continuously bubbling nitrogen (or air) into the reaction medium. Once the heating cycle is complete, the tube was cooled to ambient temperature, the tube is removed, and the cycloimmonium salts are filtered off and were purified by recrystallization from an appropriate solvent.

4-(4-Chlorophenyl)-1-[2-oxo-2-phenylethyl]pyrimidinium bromide (4a). According to general procedure A from $2(0.95 \mathrm{~g}, 5 \mathrm{mmol})$ and $\omega$-bromoacetophenone $(0.959 \mathrm{~g}, 5 \mathrm{mmol})$ to obtain 4a (1.1885g, 61\%). 4a: $\mathrm{mp} 205-206^{\circ} \mathrm{C}$ (white-yellow crystals, recrystallized from diethyl ether). IR (KBr): 1625 (s, C=O), 1693, 1590, 1463, 1341, 1090 (s-m, C=C, C=N arom), 832, 761 (s, C-H aromdef), 482 (w, C-Cl), 3035 (w, C-H arom), 2926 (w, C-Halif) cm ${ }^{-1} .{ }^{1} \mathrm{H}$ NMR (DMSO $\left.d_{6}\right) \delta$ : $9.85(1 \mathrm{H}, \mathrm{s}), 9.48-9.46(1 \mathrm{H}, \mathrm{d}, J=6.8 \mathrm{~Hz}), 9.06-9.05(1 \mathrm{H}, \mathrm{d}, J=6.8 \mathrm{~Hz}), 8.52-8.49(2 \mathrm{H}, \mathrm{d}, J=$ $8.2 \mathrm{~Hz}), 8.13-8.11(2 \mathrm{H}, \mathrm{d}, J=7.8 \mathrm{~Hz}), 7.83-7.78(3 \mathrm{H}, \mathrm{m}), 7.70-7.67(2 \mathrm{H}, \mathrm{t}, J=7.8,7.6 \mathrm{~Hz}), 6.55$ $(2 \mathrm{H}, \mathrm{s}) .{ }^{13} \mathrm{C}$ NMR(DMSO $\left.d_{6}\right) \delta: 62.53$ (C-7), 118.24 (C-5), 128.36 (C-10), 129.20 (C-11), 129.90 (C-3’), 131.02 (C-2'), 131.77 (C-4'), 133.36 (C-1'), 134.85 (C-12), 139.92 (C-9), 153.33 (C-6), 154.46 (C-2), 167.62 (C-4), 190.24 (C-8, keto). Anal. Calcd. for $\mathrm{C}_{18} \mathrm{H}_{14} \mathrm{~N}_{2} \mathrm{OBrCl}$ : C, 55.481; H, $3.621 ; 7.189$. Found: C, 55.35; H, 3.69; N, 7.08\%.

4-(4-Chlorophenyl)-1-[2-(4-bromophenyl)-2-oxoethyl]pyrimidinium bromide (4b). According to general procedure A from $2(0.95 \mathrm{~g}, 5 \mathrm{mmol})$ and $\omega$-bromo-4-bromo-acetophenone $(1.39 \mathrm{~g}$, $5 \mathrm{mmol})$ to obtain $\mathbf{4 b}(1,4275 \mathrm{~g}, 61 \%) .4 \mathbf{b}: \mathrm{mp} 246-247{ }^{\circ} \mathrm{C}$ (colourless crystals, recrystallized from diethyl ether). IR ( $\mathrm{KBr})$ : 1628 (s, C=O), 1698, 1587, 1453, 1081 (s-m, C=C, C=Narom), 830 
(s, C-H aromdef), 482 (w, C-Cl), 2919 (w, C-H $\mathrm{Halif}_{\text {) }}, 3040$ (w, C-H $\mathrm{Hrom}$ ) cm ${ }^{-1} .{ }^{1} \mathrm{H}$ NMR (DMSO $\left.d_{6}\right) \delta$ : $9.84(1 \mathrm{H}, \mathrm{s}), 9.47-9.45(1 \mathrm{H}, \mathrm{d}, J=6.8 \mathrm{~Hz}), 9.06-9.04(1 \mathrm{H}, \mathrm{d}, J=6.8 \mathrm{~Hz}), 8.51-8.49(2 \mathrm{H}, \mathrm{d}, J=$ $8.4 \mathrm{~Hz}), 8.05-8.03(2 \mathrm{H}, \mathrm{d}, J=8.0 \mathrm{~Hz}), 7.91-7.89(2 \mathrm{H}, \mathrm{d}, J=8.0 \mathrm{~Hz}), 7.80-7.78(2 \mathrm{H}, \mathrm{d}, J=8.4$ $\mathrm{Hz}), 6.54(2 \mathrm{H}, \mathrm{s}) .{ }^{13} \mathrm{C}$ NMR(DMSO $\left.d_{6}\right) \delta: 62.13(\mathrm{C}-7), 117.95(\mathrm{C}-5), 128.66(\mathrm{C}-12), 129.60(\mathrm{C}-$ 11), 129.94 (C-3'), 130.72 (C-10), 131.47 (C-4'), 131.99 (C-2'), 132.17 (C-1'), 139.65 (C-9), 153.00 (C-6), 154.11 (C-2), 167.38 (C-4), 189.36 (C-8, keto). Anal. Calcd. for $\mathrm{C}_{18} \mathrm{H}_{13} \mathrm{~N}_{2} \mathrm{OBr}_{2} \mathrm{Cl}$ : C, 46.14; H, 2.79; N, 5.98. Found: C, 46.04; H, 2.83; N, 5.82\%.

4-(4-Chlorophenyl)-1-[2-(4-nitrophenyl)-2-oxoethyl]pyrimidinium bromide (4c). According to general procedure A from $2(0.95 \mathrm{~g}, 5 \mathrm{mmol})$ and $\omega$ - bromo-4- nitro-acetophenone $(1.22 \mathrm{~g}$, $5 \mathrm{mmol})$ to obtain $4 \mathrm{c}(1,5213 \mathrm{~g}, 70 \%)$. 4c: $\mathrm{mp} 215-217{ }^{\circ} \mathrm{C}$ (pale-yellow crystals, recrystallized from diethyl ether). IR (KBr): $1626(\mathrm{~s}, \mathrm{C}=\mathrm{O}), 1708,1589,1448,1341,1092\left(\mathrm{~s}, \mathrm{C}=\mathrm{C}, \mathrm{C}=\mathrm{N}_{\text {arom}}\right)$,

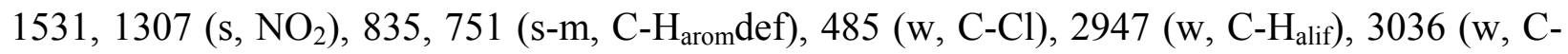
$\mathrm{H}_{\text {arom }} \mathrm{cm}^{-1} .{ }^{1} \mathrm{H}$ NMR (DMSO d $\left.d_{6}\right) \delta: 9.93(1 \mathrm{H}, \mathrm{s}), 9.56-9.54(1 \mathrm{H}, \mathrm{d}, J=6.8 \mathrm{~Hz}), 9.12-9.10(1 \mathrm{H}, \mathrm{d}$, $J=6.8 \mathrm{~Hz}), 8.50-8.45(4 \mathrm{H}, \mathrm{m}), 8.36-8.34(2 \mathrm{H}, \mathrm{d}, J=8.4 \mathrm{H}), 7.76-7.74(2 \mathrm{H}, \mathrm{d}, J=8.4 \mathrm{~Hz}), 6.71$ $(2 \mathrm{H}, \mathrm{s}) .{ }^{13} \mathrm{C}$ NMR (DMSO d $\left.d_{6}\right) \delta: 62.54$ (C-7), 118.00 (C-5), 123.86 (C-11), 129.57 (C-3'), 129.61 (C-10), 130.73 (C-2'), 131.41 (C-4'), 137.82 (C-1'), 139.69 (C-9), 150.28 (C-12), 152.96 (C-6), 154.07 (C-2), 167.45 (C-4), 189.43 (C-8, keto). Anal. Calcd. for $\mathrm{C}_{18} \mathrm{H}_{13} \mathrm{~N}_{3} \mathrm{O}_{3} \mathrm{BrCl}$ : C, 49.74; H, 3.01; N, 9.67. Found: C, 49.65; H, 3.10; N, 9.61\% .

4-(4-Chlorophenyl)-1-[2-(4-methoxyphenyl)-2-oxoethyl]pyrimidinium bromide (4d). According to general procedure A from $2(0.95 \mathrm{~g}, 5 \mathrm{mmol})$ and $\omega$-bromo-4-methoxyacetophenone $(1.1484 \mathrm{~g}, 5 \mathrm{mmol})$ to obtain $4 \mathbf{d}(1,1121 \mathrm{~g}, 53 \%) .4 d$ : $\mathrm{mp} 182-183{ }^{\circ} \mathrm{C}$ (yellow crystals, recrystallized from diethyl ether). IR (KBr): $16278(\mathrm{~s}, \mathrm{C}=\mathrm{O}), 1671,1594,1452,1345$, 1095 (s-m, C=C, C=N arom), 1246 (s-m, C-O-C), 833, 787 (s, C-H arom def), 476 (w, C-Cl), 2841 (w, C-H alph (OCH3)), 2942 (w, C-H alph), 3014 (w, C-H arom) $\mathrm{cm}^{-1} .{ }^{1} \mathrm{H}$ NMR (DMSO d 6 ) $\delta: 9.78(1 \mathrm{H}$, s), 9.42-9.38 (1H, d, $J=6.6 \mathrm{~Hz}), 9.02-8.98(1 \mathrm{H}, \mathrm{d}, J=6.6 \mathrm{~Hz}), 8.49-8.45(2 \mathrm{H}, \mathrm{d}, J=8.2 \mathrm{~Hz})$, 8.08-8.04 (2H, d, $J=8.6 \mathrm{~Hz}), 7.79-7.75(2 \mathrm{H}, \mathrm{d}, J=8.2 \mathrm{~Hz}), 7.19-7.15(2 \mathrm{H}, \mathrm{d}, J=8.6 \mathrm{~Hz}), 6.42$ $(2 \mathrm{H}, \mathrm{s}), 3.88\left(3 \mathrm{H}, \mathrm{s}, \mathrm{OCH}_{3}\right) .{ }^{13} \mathrm{C} \mathrm{NMR}\left(\mathrm{DMSO} d_{6}\right) \delta: 62.10(\mathrm{C}-7), 117.64(\mathrm{C}-5), 153.01$ (C-6), 154.11 (C-2), 167.41 (C-4), 189.69 (C-8, keto). Anal. Calcd. for $\mathrm{C}_{19} \mathrm{H}_{16} \mathrm{~N}_{2} \mathrm{O}_{2} \mathrm{BrCl}$ : C, 54.37; $\mathrm{H}$, 3.84 ; N, 6.67. Found: C, 54.25; H, 3.78; N, 6.48\%.

\section{General procedure $\mathbf{C}$ to obtain pyrimidinium ylides}

4-(4-Chloro-phenyl)-pyrimidinium salt $(1 \mathrm{mmol})$ was dissolved in $50 \mathrm{~mL}$ water-ethanol (1:1) and treated with a $40 \%$ aqueous solution of $\mathrm{K}_{2} \mathrm{CO}_{3}$. The ylide was filtered off, washed with a great amount of water, and dried under vacuum.

4-(4-Chlorophenyl)pyrimidinium 4-nitrobenzoyl methylide (5c). According to general procedure $\mathrm{C}$ from $4 \mathrm{c}(0.4346 \mathrm{~g}, 1 \mathrm{mmol})$ and a $40 \%$ aqueous solution of $\mathrm{K}_{2} \mathrm{CO}_{3}$ to obtain $5 \mathrm{c}$ (0.3502, 99\%). 5c: $\mathrm{mp} 168-170{ }^{\circ} \mathrm{C}$ (cherry coloured compound, recrystallized from water). IR (KBr): 1595 (s, C=O), 1700, 1587, 1448, 1095 (s-m, C=C, C=N arom), 1520, 1337 (s, $\left.\mathrm{NO}_{2}\right), 827$, 750 (s-m, C-H arom def), 488 (w, C-Cl), 3086 (w, C-Harom) $\mathrm{cm}^{-1} .{ }^{1} \mathrm{H}$ NMR (DMSO $d_{6}$ ) $\delta: 10.75$ $(1 \mathrm{H}, \mathrm{s}), 9.26-9.24(1 \mathrm{H}, \mathrm{d}, J=8.4 \mathrm{~Hz}), 8.79-8.77(1 \mathrm{H}, \mathrm{d}, J=8.4 \mathrm{~Hz}), 8.38-8.20(4 \mathrm{H}, \mathrm{m}), 8.06-$ 
$8.04(2 \mathrm{H}, \mathrm{d}, J=8.4 \mathrm{~Hz}), 7.53-7.42(3 \mathrm{H}, \mathrm{m})$. Anal. Calcd. for $\mathrm{C}_{18} \mathrm{H}_{12} \mathrm{~N}_{3} \mathrm{O}_{3} \mathrm{Cl}$ : N, 11.878. Found: $\mathrm{N}, 11.79 \%$.

4-(4-Chlorophenyl)pyrimidinium benzoyl methylide (5a). According to general procedure $\mathrm{C}$ from $4 \mathrm{a}(0.3895 \mathrm{~g}, 1 \mathrm{mmol})$ and a $40 \%$ aqueous solution of $\mathrm{K}_{2} \mathrm{CO}_{3}$ to obtain $5 \mathrm{a}(0.3056,99 \%)$. 5a: $\mathrm{mp} 188-193{ }^{\circ} \mathrm{C}$ (orange compound, recrystallized from water). IR (KBr): 1636 (s, large, $\mathrm{C}=\mathrm{O}$ ), 1678, 1585, 1427, 1086 (s-m, C=C, C=N arom), 818, 762 (s-m, C-H aromdef), 495 (s, C-Cl), 3040 (w, C-H $\mathrm{H}_{\text {arom }}$ ), 2924 (w, C-Halph) cm $\mathrm{cm}^{-1}$. Anal. Calcd. for $\mathrm{C}_{18} \mathrm{H}_{13} \mathrm{~N}_{2} \mathrm{OCl}$ : N, 9.07. Found: N, $8.87 \%$.

4-(4-Chlorophenyl)pyrimidinium 4-bromobenzoyl methylide (5b). According to general procedure $\mathrm{C}$ from $\mathbf{4 b}(0.4686 \mathrm{~g}, 1 \mathrm{mmol})$ and a $40 \%$ aqueous solution of $\mathrm{K}_{2} \mathrm{CO}_{3}$ to obtain $5 \mathbf{b}$ (0.3837, 99\%). 5b: $\mathrm{mp} 205-210{ }^{\circ} \mathrm{C}$ (red - orange compound, recrystallized from water). IR (KBr): 1629 (s, large, $\mathrm{C}=\mathrm{O}), 1679,1582,1455,1092$ (s-m, C=C, C=N arom), 830 (s, C- $\mathrm{H}_{\text {arom }}$ def), 496 (w, C-Cl), 3050 (w, C-Harom), 2920 (w, C-Halph) cm ${ }^{-1}$. Anal. Calcd. for $\mathrm{C}_{18} \mathrm{H}_{12} \mathrm{~N}_{2} \mathrm{OBrCl}$ : N, 7.23. Found: N, 7.14\%.

4-(4-Chlorophenyl)pyrimidinium 4-methoxybenzoyl methylide (5d). According to general procedure $\mathrm{C}$ from $4 \mathbf{d}(0.4197 \mathrm{~g}, 1 \mathrm{mmol})$ and a $40 \%$ aqueous solution of $\mathrm{K}_{2} \mathrm{CO}_{3}$ to obtain $5 \mathbf{d}$ (0.3354, 99\%). 5d: $\mathrm{mp} 185-190{ }^{\circ} \mathrm{C}$ (orange compound, recrystallized from water). IR (KBr): 1634 (s, C=O dimer), 1671, 1594, 1090 (s-m, C=C, C=N arom), 1261 (m, C-O-C), 480 (w, C-Cl), 2842 (s, C-H $\mathrm{H}_{\text {alph }}(\mathrm{OCH} 3)$ ), 3020 (w, C-H $\left.\mathrm{H}_{\text {arom }}\right), 2930$ (w, C-H $\mathrm{H}_{\text {alph }} \mathrm{cm}^{-1}$. Anal. Calcd. for $\mathrm{C}_{19} \mathrm{H}_{15} \mathrm{~N}_{2} \mathrm{O}_{2} \mathrm{Cl}: \mathrm{N}, 8.27$. Found: N, 8.10\%.

\section{Acknowledgements}

CNCSIS Bucuresti is thanked for grant no.1322/2003, for financial support. Also, we wish to thank Prof. Mircea Constantinescu for the HYPERCHEM program (version 5.02 for Windows 95- Molecular Modeling System, Hypercube, Inc. Gainesville.USA).

\section{References}

1. Zugravescu, I.; Petrovanu, M. In N-Ylid Chemistry; McGraw-Hill: London, 1976; pp 95-314 and references cited therein.

2. Padwa, A. Ed. In 1,3-Dipolar Cycloaddition Chemistry; Wiley: New York, 1984; Vol. 2, Ch. 12 and $\mathrm{Ch} .13$ and the references cited therein.

3. Klamann, D.; Hagen, H. In Houben-Weyl, Organische Stickstoff-Verbindungen mit einer C, $N$-Doppelbindung, $E_{14 b}$, Thieme: Stuttgart, New York, 1991; Teil 1, pp 1-160, and references cited therein.

4. Osmialowski, B.; Janota, H.; Gawinecki, R. Polish J. Chem. 2003, 77, 169. 
5. Butler, R. N.; Coyne, A. G.; McArdle, P.; Cunningham, D.; Burke, L. A. J. Chem. Soc., Perkin Trans. 1 2001, 12, 1391.

6. Wanda, S. Curr. Org. Chem. 2003, 7, 995.

7. Iuhas, P. C.; Georgescu, F.; Georgescu, E.; Draghici, C.; Caproiu, M. T. Rev. Roum. Chim. 2001, 46, 1145 and 893.

8. Minguez, M. J.; Vaquero, J. J.; Alvarez-Builla, J.; Castano, O.; Andres, J. L. J. Org. Chem. 1999, 64, 7788 .

9. Woisel, P.; Surpățeanu, G.; Delatre, F.; Bria, M. Eur. J. Org. Chem. 2001, 1407.

10. Druta, I.; Dinica, R.; Bacu, E.; Humelnicu, I. Tetrahedron 1998, 54, 1081.

11. Tsuge, O.; Kanemasa, S.; Takenaka, S. Bull. Chem. Soc. Jpn. 1985, 58, 3137.

12. Mangalagiu, I. I.; Caprosu, M.; Mangalagiu, G.; Zbancioc; Petrovanu, M. ARKIVOC 2002, (iii), 73.

13. Caprosu, M.; Andrei, M.; Mangalagiu, G.; Petrovanu, M.; Mangalagiu, I. I. ARKIVOC 2001, (ii), 66.

14. Mangalagiu, I. I.; Petrovanu, M. Tetrahedron 1997, 53, 4411.

15. Mangalagiu, I. I.; Mangalagiu, G.; Deleanu, C.; Drochioiu, G.; Perovanu, M. Tetrahedron 2003, 59, 111.

16. (a). Mangalagiu, G.; Mangalagiu, I. I.; Olariu, R.; Petrovanu, M. Synthesis 2000, 2047. (b) Mangalagiu , G.; Mangalagiu, I. I.; Olariu, R.; Petrovanu, M. An. Stiint. Univ. Al.I.Cuza Iasi 2000, 8, 151; Chem. Abstr. 2000, 134, 207459.

17. Mangalagiu, G.; Mangalagiu, I. I.; Humelnicu, I.; Petrovanu, M. Eur. J. Org. Chem. 1999, 703.

18. Mangalagiu, G.; Ungureanu, M.; Grosu, G.; Mangalagiu, I. I. Ann. Pharm. Fr. 2001, 59, 139.

19. Caprosu, M.; Roman, M.; Olariu, I.; Dima, St.; Mangalagiu, I. I.; Petrovanu, M. J. Heterocycl. Chem. 2001, 38, 495.

20. Mangalagiu, I. I.; Baban, C.; Mardare, D.; Rusu, G. Appl. Surface Science 1997, 108, 205.

21. Lloung, M.; Loupy, A.; Marquend, S.; Petit A. Heterocycles 2004, 63, 297.

22. Yadav, L. D. S.; Singh, A. Synthesis 2003, 2395.

23. Yu, X. C.; Huang, X. Synlett 2002, 1895.

24. Deng, Y. J.; Hlasta, D. J. Org. Lett. 2002, 4017.

25. Rissafi, B.; Rachiqi, N.; Louzi, A.; Loupy, A.; Petit, A.; Fkih-Tetouani, S. Tetrahedron 2001, 57, 2761.

26. Dinica, R. M.; Pettinari, C. Heterocycl. Commun. 2001, 7, 381.

27. Loupy, A.; Bougrin, K.; Soufiaoui, M.; Jacquault, P. New J. Chem. 1995, 19, 213.

28. Zbancioc; Mangalagiu, G.; Dima, St.; Moldoveanu, C.; Petrovanu, M.; Mangalagiu, I. I. An. Stiint. Univ. Al.I.Cuza'Iasi 2002, 10, 146.

29. Rodriguez, H.; Perez, R.; Suarez, M.; Lam, A.; Cabrales, N.; Loupy, A. Heterocycles 2001, 55, 2291.

30. Perez, E.; Sotelo, E.; Loupy, A.; Mocelo, R.; Suarez, M. Heterocycles 1996, 43, 3539.

31. Bredereck, H.; Gompper, R.; Rempfer, H.; Klemm, K.; Keck, H. Chem. Ber. 1959, 92, 329. 
32. Bredereck, H.; Gompper, R.; Geiger, B. Chem. Ber. 1960, 93, 1402.

33. Kröhnke, E. Ber. 1935, 68, 1177.

34. Salem, L. J. Am. Chem. Soc. 1968, 90, 543.

35. Herdon, W. C. Chem. Rev. 1972, 72, 157.

36. Hudson, R. F. Angew.Chem. 1973, 85, 63.

37. Dewar, M. J. S. J. Am. Chem. Soc. 1985, 107, 3902.

38. Stewart, J. J. P. J. Comp. Chem. 1989, 10, 209.

39. Mangalagiu, I. I.; Olariu, R.; Caprosu, M.; Dorohoi, D.; Cotlet, M.; Petrovanu, M. An. Stiint. Univ. Al.I.Cuza Iasi 1999, 7, 313; Chem. Abstr. 2000, 133, 192853. 